\title{
STRATEGI COPING PEREMPUAN TERHADAP STANDARISASI CANTIK DI MASYARAKAT
}

\author{
Iin Rizkiyah, Nurliana Cipta Apsari \\ Universitas Padjadjaran, Indonesia \\ iinrizkiyah@gmail.com,nurliana.cipta.apsari@unpad.ac.id \\ Julina \\ Universitas Islam Negeri Sultan Syarif Kasim Riau, Indonesia \\ julina@uin-suska.ac.id
}

\begin{abstract}
$A B S T R A C T$
Beauty is what all women expect. The purpose of this paper is to build positive coping on women in responding to beautiful standardization. This is a literature research of relevant articles, journals, and books. The author describes the diverse relativity of beautiful standardization and coping strategies undertaken by women as an effort to fulfill the ideal of beautiful standardization in their environment. The results found that the ideal beautiful construction prevailing in society will always be there. There are two coping strategies that focus on (1) overcoming problems of lack of beauty with certain treatments and (2) modifying emotions by changing understanding of the meaning of beauty. Women are able to do positive coping to distort their negative thoughts about beauty.
\end{abstract}

Keywords: Beautiful Standarization; Emotional-Focused Coping; Problem-Focused Coping

\begin{abstract}
ABSTRAK
Cantik merupakan hal yang diharapkan semua perempuan. Tujuan penelitian ini untuk mengetahui coping positif pada perempuan dalam menyikapi standarisasi cantik. Penelitian ini menggunakan pendekatan kualitatif dengan metode analisis konten dengan cara menjabarkan relative standar cantik dari artikel, jurnal dan buku. Penulis menjabarkan relativitas standarisasi cantik yang beragam dan strategi coping yang dilakukan oleh perempuan sebagai upaya pemenuhan standarisasi cantik ideal di lingkungannya. Hasil penelitian menemukan bahwa konstruksi cantik ideal yang berlaku di masyarakat akan selalu ada. Terdapat dua strategi coping yang terfokus pada (1) mengatasi masalah kurang cantik dengan perawatan tertentu dan (2) memodifikasi emosidengan cara mengubah pemahaman tentang makna cantik. Perempuan mampu melakukan coping positif untuk mendistorsi pemikiran negatifnya akan kecantikan.
\end{abstract}

Kata Kunci: Coping Emosi; Coping Masalah; Standarisasi Cantik 


\section{PENDAHULUAN}

Bagi perempuan, kecantikan memiliki peran dan arti sangat penting. Perempuan diibaratkan sebagai sosok yang sangat memuja arti dan nilai kecantikan. Meskipun gerakan emansipasi perempuan telah marak digaungkan, tetapi alam bawah sadar perempuan masih dikontrol oleh perasaan tentang kondisi diri secara fisik, yaitu obsesi tentang kecantikan (Wolf, 2002). Makna kecantikan sendiri seperti diungkapkan Wendy Chapkins merupakan politik penampilan yang tidak terbatas pada segi psikologi dan nilai seni dari perempuan dan laki-laki secara individual, tetapi telah menjadi mesin kebudayaan global, melibatkan iklan, media dan industri dalam konstruksi standar normatif dari kecantikan yang harus dicapai setiap perempuan di seluruh dunia (Kompas, 2001).

Adanya standarisasi yang terjadi di kalangan perempuan tersebut mengakibatkan kelompok-kelompok tertentu menjadi termarginalkan karena tidak sesuai standar yang sudah di konstruksi lingkungannya (Aprilita \& Listyani, 2016). Pemahaman sebagian masyarakat atas standar tersebut dipangaruhi oleh kekuatan 'media' dalam mengkonstruksi kecantikan. Di dalam media terbentuk suatu pandangan perempuan dengan tubuh ideal dan digambarkan sebagai sosok yang sehat dan bahagia, kemudian hal ini dilanggengkan oleh industri kapitalis dalam mengkonstruksi pengertian cantik dan tubuh ideal. Akibatnya, Naomi Wolf (2002) mengatakan perempuan, baik tua atau muda sangat takut akan penuaan, perempuan yang kurus maupun gemuk pun harus berjuang untuk mendapatkan bobot tubuh yang ideal (Arsitowati, 2017).

Proses konstruksi tersebut sering kali menjadikan perempuan sebagai objek visualisasi di media dan menciptakan standar tubuh perempuan ideal. Media itu disebarkan melalui koran, majalah, radio dan televisi serta menjadi tuntunan masyarakat di bumi ini, tuntunan tersebut di dikte melalui berbagai produk kecantikan yang disesuaikan dengan image yang diciptakan oleh media, sehingga perempuan sering kali merasa tidak puas dengan tubuhnya. Di dalam iklan citra kecantikan dan tubuh ideal digambarkan sebagai sosok perempuan yang memiliki tinggi semampai, langsing, berkulit putih, dengan wajah tanpa noda atau jerawat, dan figur yang sempurna bak model di majalah. Seperti di dalam iklan Slim Woman at Work dimana perempuan ideal ditunjukan dengan bertubuh langsing yang dapat melewati celah sempit tanpa mengalami kesulitan, dan di iklan Lady in Full Elevator dimana perempuan dengan bentuk tubuhnya yang 
langsing bisa melewati pintu elevator yang hampir tertutup. Konstruksi cantik dengan bentuk tubuh yang langsing ini diyakini oleh banyak perempuan sebagai kecantikan ideal (Mirwanti, 2010).

Di era industri 4.0 sekarang ini, konstruksi citra cantik tidak hanya digambarkan dalam iklan atau majalah saja, tetapi juga melalui media sosial. Salah satu media sosial yang sering digunakan adalah Instagram (APJII, 2016). Reprenstasi cantik dalam media sosial intagram memunculkan istilah body goals. Menurut kamus Webster's (1995), goals memiliki arti sesuatu yang anda coba lakukan atau sesuatu yang ingin anda capai. Maka body goals memiliki arti tubuh yang ingin dicapai. Namun body goals ini sendiri menjadi istilah untuk menggambarkan bagaimana idealnya tubuh seseorang. Body goals mulai bermunculan dari unggahan foto artis atau selebgram yang memiliki followers cukup banyak dan pengaruh cukup besar dengan menunjukan bagaimana standar kecantikan dan bagaimana seharusnya gambaran ideal fisik seseorang (Kharizta, 2018). Unggahan foto-foto tersebut sering kali kaum perempuan membanding-bandingkan diri mereka dengan foto dalam unggahan tersebut. Karena mereka menganggap hal tersebut sebagai kompetisi yang harus dicapai untuk menjadi yang paling cantik (Aprilita \& Listyani, 2016). Hal ini tidak hanya semata-mata untuk kebutuhan fisiologis perempuan saja, tetapi standar kecantikan yang harus dipenuhi ini berhubungan dengan harga diri dan identitas sosial untuk mendapatkan kebahagiaan seseorang (Chervenic, 2015).

Dampak dari hal di atas, banyak perempuan yang mulai membenci dirinya karena tidak memenuhi standard kecantikan yang digambarkan oleh media. Kebencian tersebut bukan tidak mungkin mengarah kepada hal-hal negatif seperti diet ketat yang membahayakan kesehatan, eating disorder seperti bulimia dan anoreksia. Dari kebencian itu memunculkan kekhawatiran atau insecurity dalam diri perempuan sehingga terobsesi untuk memenuhi standard kecantikan yang berlaku di lingkungan sosialnya (Aprilita \& Listyani, 2016). Kharitza (2018) menemukan dari segi body image 100\% remaja putri yang telah diwawancarai merasa tidak puas dengan bentuk fisik mereka, sedangkan jika dilihat dari segi self-esteem, sebanyak $40 \%$ merasa tidak percaya diri dengan bentuk fisiknya, namun sebanyak $60 \%$ lagi justru merasa baik-baik dengan bentuk fisiknya. Hal ini mengakibatkan perempuan tersebut sulit bergaul dengan teman sebayanya, merasa minder dengan orang lain dan menjadi mudah merasa gagal (Kharizta, 2018). Naomi Wolf (2002) mengatakan bahwa perempuan rela menderita dengan melakukan diet dan 
menghabiskan banyak waktu dan materi untuk merawat tubuh agar langsing, indah dan cantik selayaknya tuntutan media. Sebaliknya, sebagian kalangan yang tidak dapat memenuhi standard tersebut akan termarginalkan hingga mengalami 'bodyshaming' (Sakinah, 2018).Bodyshame merupakan perasaan sadar diri seseorang yang dihasilkan dari persepsi mengenai kegagalan untuk memiliki tubuh sesuai standar tubuh ideal di lingkungannya (Lampont, 2018, dalam Cahyani, 2018). Hal ini mengakibatkan seseorang kehilangan pandangan positif pada dirinya dan menurunkan kepercayaan diri (self-esteem) yang dimilikinya.

Tindakan bodyshaming merupakan suatu tindakan melecehkan anggota tubuh yang ditunjukan kepada siapa saja yang tidak memenuhi standar kecantikan. Bodyshaming disebut juga sebagai salah satu bentuk dari bullying (kekerasan verbal) yang menyebabkan trauma psikis karena ucapan yang menyakitkan atau tidak menyenangkan (Setiawati, dalam Putri, Kuntjara, \& Sutanto, 2018). Faktor penyebab tindakan ini menurut pengamat sosial Rahmawati (2018) dikarenakan pertama, kultur patron yang berpandangan bahwa orang yang berkuasa dapat melakukan apapun, kedua, budaya patriarki yang tubuhnya memiliki banyak elemen untuk dijadikan objek lelucon, ketiga, minimnya pengetahuan bodyshaming sebagai perilaku yang menyimpang dan memiliki hukum pidana, dan keempat, post kolonial yaitu pandangan yang mengakar dimana orang Indonesia selalu melihat sesuatu yang kebarat-baratan seperti putih, tinggi, mancung adalah sempurna, sedangkan pendek, hitam dan bertubuh besar adalah buruk (www.jawapos.com, 2018).Munculnya sterotipe ini mengakibatkan perempuan kehilangan rasa percaya diri (Self-Esteem), mengganggu rasa aman (Insecure Feeling) dalam kehidupan sehari-hari, dan setelah itu berupaya untuk menjadi ideal (Strive to be Ideal) walaupun dengan cara yang tidak sehat dan membahayakan diri sendiri (Sakinah, 2018). Dampak bahaya dari citra cantik ini mendorong penulis untuk mengkaji pentingnya menyikapi hal ini dengan bijak dalam menghadapi berbagai konstruksi standar kecantikan yang harus dipenuhi. Salah satu upaya yang dapat dilakukan oleh individu ialah Strategi Coping. Individu tidak akan membiarkan efek negatif dari kondisi tersebut secara terus menerus, ia akan melakukan suatu tindakan untuk mengatasinya yang disebut Coping (Lazarus dan Folkman, 1984). Strategi Coping ini bertujuan untuk mengatasi situasi dan tuntutan yang dirasa menekan, menantang, membebani dan melebihi kemampuan yang dimiliki individu. 


\section{METODE}

Penelitian ini menggunakan metode deskriptif dengan mengkaji berbagai literatur dari artikel-artikel, jurnal-jurnal, dan buku yang relevan. Metode deskriptif merupakan salah satu jenis yang membahas secara mendalam kondisi sosial yang terjadi di masyarakat. Masalah yang akan diteliti di deskripsikan secara terperinci sehingga menghasilkan rekomendasi dalam menyelesaikan masalah tersebut. Dalam penelitian ini, dibahas secara terperinci mengenai berbagai teori tentang standarisasi cantik dan strategi yang dapat digunakan oleh perempuan dalam menyikapi standarisasi cantik yang berkembang di masyarakat. Selain itu, digunakan pula kuesioner yang menanyakan pendapat informan terkait dengan topik yang diteliti. Kuesioner disebarkan secara snowball sampling yaitu dengan meminta bantuan kepada informan untuk menyebarluaskan lagi kepada jejaring yang dimilikinya.

\section{HASIL PENELITIAN}

\section{Awal Mula Konstruksi Cantik Muncul di Masyarakat}

Objektivitas visual perempuan sebagai suatu keindahan yang dinikmati oleh kalangan pria dan media tidak hanya berkembang di era saat ini saja. Tetapi, hal ini telah berkembang di era 69 SM yang ditunjukan oleh sosok Cleopatra. Mark Tungate menuliskan dalam Branded Beauty bahwa Cleopatra dianggap sebagai ikon kecantikan paling awal dilihat dari rutinitas kecantikannya. Orang Mesir percaya bahwa tidak hanya kebersihan, tetapi keindahan dan keshalehan pun berkontribusi menciptakan standar kecantikan perempuan. Rutinitas kecantikan itu dilakukan dengan membersihkan tubuh (mandi), membersihkan gigi, luluran dengan tanah dan abu, obat anti keriput pada kulit, menggunakan kohl yang digunakan sebagai eyeliner, dll. Hingga citra cantik ini membawa keuntungan besar bagi pedagang kecantikan di Mesir. Di abad kegelapan dan kebangkitan, citra cantik ditunjukan dengan adanya tuntutan agar terlihat awet muda, perempuan rela membayar dengan harga mahal walau itu menyakitkan bagi tubuh mereka, sedangkan di abad ke-16 citra cantik ditunjukan perempuan ketika menggunakan korset yang dibuat untuk menonjolkan payudara dan mengecilkan pinggang. Dan di abad ke-19, penggunaan krim kulit dan pembersih wajah mulai diiklankan kepada semua kelangan. Seiring berjalannya waktu produk kecantikan berkembang menjadi sebuah 
industri. Dan semakin melanggengkan perspektif standarisasi cantik dengan menjadikan tubuh perempuan sebagai objek visual (Chervenic, 2015).

Dalam pandangan evolusioner, karakteristik cantik digambarkan sebagai kesuburan (reproduksi), ditandai dengan bentuk bibir penuh, kulit halus, mata jernih, rambut berkilau, ekspresi wajah dan aura cantik yang tinggi. Karakteristik ini menjadi puncak keindahan di setiap budaya dan menjadi keunggulan di setiap evolusionernya (Sarwer, 2003). Nomi Wolf (2002) mengatakan kriteria cantik selalu berubah dari masa ke masa, paling tidak dilihat dari sisi estetis. Seperti ketika menjelang abad ke-20, perempuan dipandang cantik jika memiliki pantat dan paha yang besar. Saat itu kesuburan menjadi lambang dari kecantikan seorang perempuan. Hal ini terjadi diberbagai negara seperti Kepulauan Fiji di Laut Pasifik, Afrika, India bahkan Indonesia. Tidak hanya tubuh subur, bahkan kegemukan menjadi lambang dari kemakmuran hidup (Permata \& Nanda, 2017). Berbeda halnya dengan citra cantik era Mao Zedong Cina, perempuan diharuskan menolak untuk menghias diri mereka seperti tidak menggunakan makeup, perhiasan, rambut yang pendek serta menolak praktik untuk membuat bentuk kaki perempuan menjadi kecil. Hal ini dilakukan untuk mengubah kebiasaan perempuan mempercantik diri dan cenderung mendorong perempuan menjadi sosok yang aktif secara politik, nasionalis dan berpendidikan baik (Permata \& Nanda, 2017). Di Indonesia, persepsi citra cantik tidak dapat didefinisikan dengan satu skema tunggal tentang kecantikan. Banyak kepercayaan di Indonesia yang meyakini nilai tradisional sebagai citra cantik. Nilai tradisional ini dibawa dari unsur-unsur lokalitas pada suatu tempat, kelompok dan kebudayaan dari keberagaman Indonesia (Prianti, 2013).

\section{Standarisasi Cantik yang Beragam}

Kecantikan sering kali dianggap sebagai suatu relativitas, artinya pandangan setiap orang terhadap konsep cantik itu berbeda-beda. Konsep kecantikan memiliki dua paradigm, yakni paradigm tradisional dan paradigma modern. Kecantikan tradisional melihat dari aspek budaya yang merujuk pada pengertian bahwa setiap masyarakat dengan budaya berbeda memiliki kriteria kecantikan yang berbeda-beda pula. Kriteria tersebut dikonstruksi berdasarkan prior knowledge atau pengetahuan terdahulu yang kemudian dibawa secara turun temurun. Selain itu, kecantikan tradisional juga mengandung unsur lokalitas yang mengacu pada tempat, 
kelompok dan budaya didalamnya. Seperti Suku Karen yang berada di Thailand, mereka memiliki persepsi bahwa perempuan yang cantik adalah perempuan yang memiliki leher panjang. Oleh sebab itu, para perempuan suku Karen ini mengalungkan leher mereka dengan tumpukan kawat yang terbuat dari kuningan sejak mereka masih gadis (Aprilita \& Listyani, 2016). Sedangkan paradigm kecantikan modern ialah citra cantik yang dibawakan oleh pengaruh media dan cenderung menyamaratakan aspek kecantikan, yaitu berupa tubuh kurus langsing, tinggi semampai, kulit putih bersih, rambut panjang, mata besar dan hidung mancung. Seperti halnya boneka Barbie yang memiliki tubuh ramping panjang, mata yang sangat besar dan bulu mata yang sangat panjang (Chervanic, 2015).

Hasil penelitian Aprilita \& Listyani (2016) berjudul Representasi Kecantikan Perempuan dalam Media Sosial Instagram ini juga menunjukkan hasil konsep citra cantik yang berbeda-beda dari setiap akun. Akun yang pertama, yakni@mostbeautyindo, citra cantik yang ditunjukkan adalah kecantikan modern dan sensual. Gaya hidup modern tersebut ditunjukkan pertama melalui penggunaan gadget berupa smartphone dan kamera, perawatan tubuh berupa masker wajah dan kegiatan di gym, serta kiblat budaya barat melalui pemakaian bikini, yang banyak terlihat dalam beberapa foto di akun@mostbeautyindo. Konsep kecantikan sensual terlihat dari penggunaan pakaian yang terbuka yang memperlihatkan tubuh perempuan, serta gesture berupa membusungkan dada, melipat kaki, dan menjulurkan lidah. Kedua, Akun @bidadarisurga_, di sisi lain menampilkan mitos kecantikan yang berbeda dari akun @mostbeautyindo. Konsep kecantikan yang ditampilkan oleh akun ini adalah kecantikan yang Islami, yakni yang taat terhadap ajaran-ajaran agama Islam. Mitos tersebut ditunjukkan melalui tanda seperti mukena, Al-Quran, dan gesture berupa senyum tipis, memejamkan mata, dan sebagainya. Mitos kecantikan tersebut membawa ideologi keagamaan. Sedangkan ketiga, pada akun@papuan_girl, representasi kecantikan yang ditampilkan adalah yang menunjukkan lokalitas, artinya kecantikan yang tidak bersifat universal dan menunjukkan keunikan serta ciri khas dari kelompok mereka, yakni Papua. Keunikan tersebut merujuk pada ciri khas perempuan Papua yang memiliki tubuh berisi, kulit kecokelatan, dan rambut keriting. Selain itu, konsep kecantikan yang diangkat oleh akun ini adalah kecantikan yang bangga dengan budaya lokal asli Papua. Dalam menghadapi keberagaman ini perempuan beradaptasi dengan membandingkan dirinya dan standarisasi cantik di lingkungannya. 
Menurut teori perbandingan sosial Festinger (1954) memprediksi bahwa perempuan dapat membandingkan diri mereka dengan standar kecantikan masyarakat untuk menilai tingkat daya tarik mereka sendiri. Sebagai contoh, Thornton dan Moore (1993) menemukan bahwa tingkap konsep diri perempuan dari daya tarik dan harga diri sosial lebih rendah setelah terpapar dengan model yang menarik secara fisik dari jenis kelamin yang sama daripada setelah terpapar dengan model sesama jenis yang secara fisik tidak menarik. Demikian pula, penelitian lain menunjukkan bahwa perempuan mengalami penurunan harga diri, tetapi peningkatan kesadaran diri, kecemasan fisik, dan ketidakpuasan tubuh setelah terpapar foto-foto model yang mencontohkan standar kecantikan utama (Thornton \& Maurice, 1997, 1999, dalam Chin Evans \& McConnell, 2003). Efek kontras fisik ini berlaku ketika perempuan membandingkan diri mereka dengan teman sesama jenis yang menarik, serta model profesional (Cash, Cash, \& Butters, 1983, dalam Chin Evans \& McConnell, 2003).

Teori Perbandingan Sosial memiliki asumsi utama bahwa setiap individu cenderung akan membanding-bandingkan dirinya dengan individu lain yang memiliki sifat-sifat dan atribut-atribut yang mirip dengannya untuk mendapatkan evaluasi positif terhadap dirinya sendiri (Afif, 2015). Teori ini memandang semua individu sebagai subjek homogen. Pada setiap individu akan dijumpai motif kompetisi sebagai motor penggerak bagi tercapainya kebutuhan untuk selalu tampil lebih unggul dan lebih baik di hadapan individu-individu lain. Tetapi, perbandingan tersebut tidak ditunjukan kepada sembarang orang. Individu yang statusnya lebih rendah sering kali menjadi sasaran perbandingan, karena apabila individu membandingkan dirinya dengan individu lain dengan status yang lebih tinggi maka kemungkinan konsep dirinya akan terancam (Afif, 2015).

Perbandingan sosial dengan status lebih tinggi untuk mencapai standar kecantikan dominan dapat menyebabkan seseorang merasa negatif tentang dirinya sendiri. Seperti halnya dalam media sosial Instagram yang sering kali menjadi alat pembanding antara realitas dan standar kecantikan yang ingin dicapai. Instagram semakin tinggi popularitasnya di kalangan masyarakat. Foto-foto yang diunggah tersebut kemudian menjadi konsumsi publik dan mempengaruhinya, khususnya terhadap kaum perempuan yang memiliki kecenderungan membandingkan diri mereka dengan perempuan lain. Tidak jarang perempuan mulai membenci dirinya sendiri karena tidak dapat tampil sebagaimana perempuan dalam media yang 
terkesan sempurna. Kebencian tersebut bukan tidak mungkin mengarah kepada hal-hal negatif seperti diet ketat, eating disorder, oprasi plastic, suntik pemutih dan lain sebagainya yang membahayakan diri sendiri, demi memenuhi keinginan untuk tampil cantik selayaknya tuntutan media (Aprilita \& Listyani, 2016). Tidak hanya itu, hal ini pun rentan akan terjadinya pelecehan atau body shiming. Oxford dictionary mendefinisikan body shaming sebagai 'Tindakan atau praktik mempermalukan seseorang dengan membuat komentar mengejek atau mengkritik tentang bentuk atau ukuran tubuhnya'. Seperti "Badan lu mirip gentong!" "Body lu mirip tiang listrik!" "Rambutlu mirip bonsai!. Pernyataan tersebut merupakan salah satu bentuk 'body shaming' mengenai konsep tubuh sebagai akibat citra cantik yang dibentuk dan disebarkan oleh media.

Afif (2015) mengatakan dalam merespon konsep diri yang sedang terancam karena perbandingan sosial, individu dapat memilih satu dari dua strategi untuk memulihkan konsep dirinya yang mengalami krisis tersebut, yaitu pertama, apakah individu itu akan memperlemah perbandingan sosial, atau kedua, memilih untuk menghindar dari perbandingan sosial dengan individu yang memiliki status lebih tinggi. Pilihan yang kedua terbukti lebih dapat membantu meningkatkan citra positif konsep diri individu (Gibbons, 1986, dalam afif, 2015). Seperti halnya Chin Evans \& McConnell (2003) dalam penelitiannya Do Racial Minorities Respond in the Same Way to Mainstream Beauty Standards? Social Comparison Processes in Asian, Black, and White Women menemukan bahwa perempuan kulit hitam memandang standar kecantikan dominan secara berbeda dari perempuan Asia dan perempuan kulit putih. Perempuan berkulit hitam dengan menggunakan strategi perlindungan diri sambil membandingkan diri mereka dengan standar kecantikan dominan menunjukan bahwa perempuan kulit hitam tidak menemukan adanya keinginan untuk mencapai standar kecantikan dominan, tetapi mereka cenderung melakukan perbandingan sosial yang relevan dengan standar kecantikan dalam kelompok kulit hitam, dan memiliki self-esteem lebih besar daripada perempuan Asia dan perempuan kulit putih

Perempuan Asia dan perempuan kulit putih cenderung mengadopsi standar mainstream kecantikan sebagai perbandingan sosial yang relevan dan melihat citra cantik sebagai suatu hal yang penting. Menurut Markus dan Kitayama (1991) hal tersebut dikarenakan orang Asia memiliki kebutuhan kuat untuk menyesuaikan diri dengan standar budaya. Orang Asia memiliki saling ketergantungan antara diri dan budaya dominan yang berlaku, ia harus berusaha untuk menyesuaikan diri dengan standar yang ditentukan oleh budaya tersebut. 
Kepatuhan terhadap norma-norma budaya ini mungkin secara psikologis merusak bagi perempuan Asia, terutama ketika mereka berupaya keras untuk mencapai citra cantik yang sulit atau bahkan tidak mungkin untuk dicapai. Refleksi ini menunjukan bahwa tingkat ketidakpuasan terhadap citra cantik bagi perempuan Asia sangat besar untuk mencapai citra cantik yang ideal, dan evaluasi diri juga harga diri lebih rendah daripada perempuan berkulit hitam. Naomi Wolf (2002) mendefinisikan cantik sebagai sesuatu yang tidak bersifat universal atau tidak dapat diubah, melainkan berbeda-beda berdasarkan konstruksi dari pemikiran masyarakat mengenai konsep cantik itu sendiri. Konstruksi tersebut dipengaruhi oleh pengetahuan yang diterima dan diyakini oleh suatu masyarakat. Tubuh merupakan objek yang penuh dengan tendensi-tendensi atas ideologi yang mengkonstruksinya. Kontruk-kontruk tersebut diciptakan dan menjadi pedoman yang harus dicontoh serta diterapkan. Seperti yang dikatakan Ella dan Yepa (2004), di Indonesia, citra cantik perempuan suku Dayak ditunjukan dengan perempuan yang tidak memiliki kulit bersih dan juga jumlah anting yang tergantung di telinganya, sehingga semakin banyak anting yang tergantung maka semakin cantik perempuan tersebut (Permata \& Nanda, 2016).

Dalam hal ini menunjukan bahwa standarisasi cantik sangat beragam dan berbeda. Ia tidak selalu berkiblat kepada citra cantik ideal yang digambarkan dalam media televisi ataupun media sosial. Cantik memiliki arti masing-masing sesuai konstruksi sosial yang berlaku di masyarakatnya. Dalam budaya Amerika tubuh dan penampilan merupakan identitas sosial untuk menjadi seorang individu. Identitas sosial ini merupakan individu-indivu dalam suatu kelompok yang senantiasa membutuhkan self-image yang positif dan menjadi representasi dari ciri-ciri kelompok tersebut (Afif, 2015). Perempuan sering kali membandingkan dirinya dengan standar kecantikan ideal tidak hanya semata-mata kebutuhan fisiologis, tetapi juga sebagai identitas diri demi mendapatkan pengakuan dan harga diri yang tinggi di masyarakat.

Pengakuan cantik pada umumnya diperoleh dari berbagai ajang kontes kecantikan baik pada level nasional dalam suatu negara maupun internasional antar Negara. Indonesia termasuk salah satu negara yang rutin mengirimkan utusan dalam ajang kontes Miss Universe atau Miss World. Menurut Hermansyah (2011) berbagai kontes kecantikan tersebut dapat berdampak negatif ketika terjadi eksploitasi perempuan di media massa dan bahkan dapat dipandang pula sebagai pelecehan terhadap perempuan. Kegiatan tersebut juga disinyalir tidak sesuai dengan 
hukum Islam. Gelaran dan misi yang diemban oleh berbagai ajang kontes kecantikan lebih banyak mudharat dibandingkan manfaatnya untuk kehidupan sosial, masyarakat, bangsa, dan negara.

\section{Strategi Coping Perempuan terhadap Standarisasi Cantik di Masyarakat}

Dalam memenuhi identitas sosial sebagai perempuan cantik, kebanyakan perempuan melakukan beberapa strategi penanganan masalah kecantikannya. Strategi tersebut disebut Coping, Coping adalah perilaku yang terlihat dan tersembunyi yang dilakukan seseorang untuk mengurangi atau menghilangkan ketegangan psikologi dalam kondisi yang penuh stres (Yani, 1997). Menurut Sarafino (2002), coping adalah usaha untuk menetralisasi atau mengurangi stres yang terjadi. Dalam pandangan Haber dan Runyon (1984), coping adalah semua bentuk perilaku dan pikiran (negatif atau positif) yang dapat mengurangi kondisi yang membebani individu agar tidak menimbulkan stress. Menurut Lazarus dan Folkman, Copingmerupakan suatu proses dimana individu mencoba untuk mengelola jarak yang ada antara tuntutan-tuntutan (baik itu tuntutan yang berasal dari individu maupun tuntutan yang berasal dari lingkungan) dengan sumber-sumber daya yang mereka gunakan dalam menghadapi keadaan menekan. Dalam konteks standar cantik, hal ini dapat didefinisikan sebagai upaya-upaya yang dilakukan individu dalam menghadapi tuntutan standarisasi cantik yang ada di lingkungannya untuk mengurangi stressful atau tekanan yang dialami.

Lazarus dan Folkman menjelaskan 2 (dua) strategi dalam melakukan coping, yaitu: Pertama, Strategi Coping berfokus pada masalah (Problem Focused Coping). Strategi coping berfokus pada masalah adalah suatu tindakan yang diarahkan pada pemecahan masalah. Individu akan cenderung menggunakan perilaku ini bila dirinya menilai masalah yang dihadapinya masih dapat dikontrol dan dapat diselesaikan. Metode yang digunakan adalah metode tindakan langsung untuk mengurangi tuntutan, peristiwa, personal atau keadaan yang mendatangkan stress lainnya. Dalam memenuhi standarisasi cantik, perempuan membeli produk-produk perawatan untuk mengatasi permasalahan dalam tubuhnya. 60\% dari 17.889 perempuan Indonesia menginginkan produk perawatan yang bisa mencerahkan kulit, 53\% konsumen ingin produk yang dapat mengecilkan pori-pori dan menghilangkan jerawat, 43\% ingin mengencangkan kulit. Mereka tergerak untuk melakukan perawatan 82\% berasal dari diri 
sendiri, 22\% berasal dari lingkungan dan 10\% berasal dari pasangan. Hal ini menunjukan bahwa perempuan lebih banyak tergerak secara mandiri dalam mengatasi standarisasi cantik yang ada di lingkungannya, termasuk jenis perawatan yang berdampak buruk terhadap tubuh perempuan.

Strategi Coping yang kedua adalah Strategi Coping berfokus pada emosi (Emotional Focused Coping). Strategi ini melakukan usaha-usaha yang bertujuan memodifikasi fungsi emosi tanpa mengubah situasi stressor secara langsung. Pengendalian ini dapat dilakukan melalui pengkonfrontasi dari tindakan penggunaan perawatan wajah yang berbahaya dengan perilaku positif menggunakan produk herbal dan pola hidup sehat. Cara lain yang digunakan dalam mengatasi masalah akibat standarisasi cantik ini adalah dengan mengubah pemahaman terhadap masalah yang dihadapi. Menurut pendekatan Cognitive Behavior Therapy pemikiran yang negatif mampu mengakibatkan timbulnya perasaan negatif dan mengakibatkan perilaku maladaptive, sehingga merekonstruksi pemikiran merupakan hal yang penting karena pikiran merupakan dasar dari perasaan dan tingkah laku individu. Dalam hal ini, diperlukan perempuan yang mampu menerima dirinya dan tidak membandingkan dirinya dengan orang lain, mampu mengetahui kesalahan dalam pemikiran dan perbuatannya, serta apabila telah melakukan perbuatan yang baik dapat dipertahankan.

\section{PEMBAHASAN}

Keberagaman standarisasi cantik sebagaimana ditunjukan pada pembahasan sebelumnya merupakan bentuk lain dari konsep cantik di era sekarang ini. Persepsi cantik sangat beragam dan sangat subjektif. Pendapat para informan dalam penelitian ini menyimpulkan bahwa standar cantik di masyarakat dapat dibedakan menjadi dua kategori yaitu cantik secara fisik dan cantik secara perilaku. Diantara yang menyebutkan standar cantik secara fisik adalah: kulit putih bersih, rambut lurus, tinggi langsing, hidung mancung, badan semampai, wajah kebule-bulean (informan nomor 1). Senada dengan pendapat tersebut, informan nomor 12 juga menyebutkan definisi cantik secara fisik yaitu memiliki kulit halus, wajah menarik, dan postur tubuh ideal. Begitu pula informan nomor 13 dengan pendapat bahwa cantik sering diartikan sebagai orang yang memiliki tubuh ideal, modis, putih, dan berpenampilan menarik 
Menurut beberapa informan tersebut, standarisasi cantik yang ada di masyarakat adalah perempuan dengan warna kulit putih. Pada kenyataannya, tidak semua perempuan Indonesia memiliki kulit yang putih. Sebagian memiliki warna kulit sawo matang dan sebagian memiliki warna kulit hitam. Kenyataan bahwa tidak semua perempuan Indonesia memiliki kulit putih membuat produk-produk kecantikan yang mengklaim dapat membuat kulit putih laku keras di pasaran. Selain warna kulit putih, rambut lurus juga menjadi ciri perempuan cantik di Indonesia. Iklan-iklan Shampo banyak menampilkan perempuan-perempuan berambut lurus yang semakin memperkuat citra cantik perempuan salah satunya memiliki rambut lurus. Standar ketiga perempuan cantik adalah memiliki tubuh yang tinggi langsing atau postur tubuh ideal. Keinginan untuk memiliki tubuh langsing membuat perempuan kerap kali melakukan diet yang jika dilakukan secara berlebihan akan dapat memberikan dampak negatif bagi tubuhnya. Ciri fisik keempat adalah memiliki hidung mancung atau hidung bangir. Sebagian besar perempuan Indonesia tidak diwarisi gen yang dapat membentuk hidung mancung secara alami. Upaya memancungkan hidung seringkali dilakukan melalui operasi plastik yang membutuhkan banyak biaya. Bahkan demi mengejar standar cantik dari sisi kemancungan hidung, perempuan tidak segan-segan bereksperimen dengan menggunakan silikon meski bukan ditangani oleh dokter ahli sehingga yang terjadi justru malpraktek yang membuat hidungnya rusak. Kriteria cantik dalam bentuk badan semampai hampir sama dengan tinggi langsing. Kriteria terakhir yaitu wajah kebule-bulean menggambarkan adanya perpaduan antara ras Indonesia dengan ras dari negara-negara lain sehingga menghasilkan kombinasi yang cantik yang berbeda dari kebanyakan perempuan Indonesia.

Definisi cantik secara fisik ini juga diperkuat dengan pendapat beberapa informan bahwa wanita tercantik menurut mereka antara lain Marie Antoinette, Sarwendah, Lady Diana, Shireen Sungkar. Beberapa perempuan ini memang mewakili ciri-ciri cantik secara fisik sebagaimana dikemukakan sebelumnya. Namun demikian, informan nomor 8 dan 11 menyatakan bahwa wanita tercantik adalah Aisyah r.a. istri Rasululloh s.a.w. walaupun tidak ada satupun yang pernah melihat gambar atau fotonya. Lebih dari sepertiga informan menyatakan bahwa wanita tercantik adalah Ibu mereka sendiri.

Kriteria cantik secara fisik selain yang telah dikemukakan oleh para informan, adalah cantik secara fisik dalam bentuk muka oval dan montok. Hal ini didasarkan pada jawaban 
informan nomor 8 yang menyatakan memiliki fisik tinggi, langsing, kulit putih bersih, muka oval, dan montok. Menurut artikel yang dimuat pada situs womentalk.com, bentuk wajah yang paling diinginkan jika seorang perempuan melakukan operasi plastik adalah bentuk berlian, oval, hati atau segitiga terbalik, persegi, dan persegi panjang. Bentuk wajah berlian memiliki ciri dahi dan rahang sempit dan tulang pipi merupakan bagian terluas dari wajah. Bentuk ini identik dengan perempuan yang feminin dan elegan. Selanjutnya bentuk wajah oval dicirikan dengan dahi sedikit lebih lebar dari dagu. Wajah dengan dahi dan tulang pipi yang lebar dengan rahang dan dagu yang sempit merupakan ciri dari wajah hati atau segitiga terbalik. Jika bentuk rahang dan dagu menonjol, serta dahi dan rahang lebih kurang sama lebarnya merupakan ciri wajah persegi. Bentuk wajah persegi panjang pada umumnya tidak disukai perempuan karena dianggap hal yang negatif untuk perempuan. Namun demikian, dengan tidak adanya standar yang pasti untuk kecantikan, perempuan dengan wajah persegi panjang seperti Victoria Beckham membuktikan dirinya tetap menjadi perempuan cantik dan banyak diidolakan.

Definisi cantik yang berikutnya adalah cantik dari sisi perilaku. Adapun informan nomor 2 yang beranggapan cantik dari sisi perilaku mengatakan bahwa akhlak dan pribadinya yang akan membuat seorang perempuan menjadi cantik. Sementara itu, informan lain yaitu informan nomor 5 mengatakan bahwa cantik itu apabila cantik hati dan kepribadian akhlak. Kecantikan dari sisi akhlak, kepribadian, atau sering disebut dengan inner beauty seringkali juga dianggap penting bagi perempuan karena kencantikan ini sifatnya tak lekang oleh waktu.

Tidak semua perempuan percaya dan mengikuti standar cantik yang ditetapkan masyarakat umum. Beberapa influenser merubah penampilannya tidak sesuai dengan konstruksi standarisasi cantik ideal yang berlaku, seperti penyanyi Agnes Mo yang dengan sengaja menghitamkan kulitnya, artis Kartika Putri yang menunjukan citra cantiknya dengan memilih berhijab, atau seperti Kekeyi Putri Cantikka beauty vlogger yang menunjukan bahwa citra cantik tidak selalu digambarkan oleh perempuan yang tinggi langsing, berkulit putih, berwajah tirus dan bermata lebar. Tetapi, setiap orang dapat menemukan definsi citra cantiknya sendiri.

Terkait dengan definisi citra cantiknya sendiri, ada informan yang menggabungkan antara kecantikan secara fisik dengan kecantikan dari sisi perilaku. Hal ini sebagai dikemukakan bahwa menurutnya, cantik adalah wanita dengan kulit bersih terawat, badan wangi, memakai 
pakaian yang cocok untuk dirinya, murah senyum, rambut dan kuku terawat baik, sikap yang anggun (informan nomor 1). Selanjutnya, informan nomor 2 menyatakan bahwa perempuan menarik dari aspek perilakunya, fisiknya dan kepribadian yang memberikan kenyamanan, dan manfaat positif bagi orang lain. Sementara informan nomor 8 menyebutkan bahwa kriteria cantik juga meliputi kepercayaan diri, kecerdasan, dan sifat kemanusiaan. Punya kepercayaan diri terhadap fisik yang dimiliki, cerdas, santun, berakhlak baik, dan memiliki sifat kemanusiaan. Informan nomor 9 pula menyatakan cantik itu berarti memiliki sifat low profile dan bumble. Lebih jauh informan nomor 10 menambahkan bahwa cantik luar harus diisi dengan cantik dari dalam. Hampir semua informan dalam penelitian ini tidak ketinggalan menyebutkan kecantikan dari sisi perilaku untuk definisi cantik menurut pendapatnya sendiri. Salah seorang informan yang menganggap bahwa Ibunya adalah perempuan paling cantik mendefinisikan cantik dengan menjadikan sosok Ibu sebagai panutan. Menurutnyacantik itu adalah dia yang berani, berani dalam segala hal bertindak, bersikap, berani jujur seperti ibu yang selalu melakukan apapun untuk keluarganya (informan nomor 3).

Perpaduan antara kecantikan fisik dan perilaku ini didukung oleh artikel yang ditulis oleh Amel di idntimes.com yang menyatakan bahwa orang yang tidak hanya mengandalkan kecantikan fisik, tapi juga kecantikan hati akan tidak berusaha menjadi orang lain, percaya pada diri sendiri dan menerima kekurangan. Cantik hati juga berarti memiliki empati, easy going, tidak gengsi, siap dan berani menghadapi sesuatu yang baru untuk kemudian beradaptasi, objektif, rendah hati, tidak pendendam, tulus, dan ciri terakhir adalah setia.

Sebagaimana dibahas sebelumnya, adanya standarisasi cantik di masyarakat dapat menimbulkan dampak negatif seperti gangguan kesehatan, merasa rendah diri, dan body shaming. Sebagian besar informan dalam penelitian ini merasa ada sesuatu yang kurang pada dirinya jika dibandingkan dengan standar cantik di masyarakat. Ketika diminta untuk menilai diri sendiri dengan skala 1-10, terdapat satu orang informan yang menilai kecantikan dirinya pada poin 4 begitu pula ada yang merasa dirinya pendek. Hal ini tidak sesuai dengan standar cantik secara fisik yaitu tinggi langsing dan semampai. Secara teori, ada dua strategi yang dapat dilakukan untuk mengatasi dampak negatif yaitu memecahkan masalah dan memodifikasi emosi. Informan yang menggunakan strategi memecahkan masalah melakukan diet untuk mengatasi sesuatu yang dirasanya kurang dari standar cantik di masyarakat (informan nomor 9). Dengan 
diet, dia berusahan untuk menjaga pola makan dan kesehatannya. Informan nomor 1 menyatakan bahwa selain menjaga penampilan bersih dan terawat, dia juga menjaga sikap yang ini berarti melakukan keseimbangan antara cantik fisik dan cantik hati. Sementara itu, informan yang menggunakan strategi memodifikasi emosi dilakukan antara lain dengan menanamkan dalam diri bahwa dia menerima apa adanya pemberian Allah (informan nomor 2). Cara lain yang dilakukan informan dalam menerapkan strategi modifikasi emosi adalah dengan selalu percaya diri dan jadikan sebagai motivasi diri (informan nomor 7). Beberapa informan menyatakan mereka menerima kondisi fisik yang Allah tetapkan pada mereka, seperti informan nomor 10 menyatakan bahwa tidak ada yang bisa dia tangani terkait dengan muka jelek, akan tetapi dia akan berusaha untuk cantik dari dalam. Begitu pula informan nomor 12 menyatakan pemberian Tuhan tidak bisa diubah. Berdasarkan pendapat para informan tersebut, dapat disimpulkan bahwa mereka telah menerapkan semua strategi coping dalam menyikapi standarisasi cantik perempuan. Beberapa menggunakan strategi memecahkan masalah, sementara yang lain menggunakan strategi memodifikasi emosi, atau gabungan dari keduanya. Alih-alih sibuk mengejar standarisasi cantik perempuan yang banyak beredar di masyarakat, mereka menyarankan untuk fokus pada mengeksplorasi kelebihan pada diri dan yang tidak kalah penting adalah mensyukuri apapun karunia yang Allah berikan.

Terkait dengan banyaknya perempuan yang berlomba-lomba mempercantik diri agar sesuai standar cantik pada umumnya, ada beberapa saran yang dikemukakan oleh para informan. Misalnya: Cantik itu tidak perlu dikejar tapi perlu dimunculkan dari hati dan kebaikan yang dilakukan pada semua makhluk Tuhan(informan nomor 2). Informan lain menyatakan cantik di Korea belum tentu cantik di Eropa, cantik di Indonesia belum tentu cantik di Thailand, cantik di Malaysia belum tentu cantik di India. Jadi kalau kita selalu memikirkan cantik untuk mengejar standar cantik di masyarakat maka itu tidak akan ada habisnya, jadi buatlah perubahan agar kita cantik versinya kita bukan cantik versi masyarakat karena itu tidak akan ada habisnya. Tetap jadi diri sendiri karena cantik yang sesungguhnya itu ada di dalam diri sendiri (informan nomor 3). Informan lain memberikan pendapat bahwa antara perilaku dan fisik adalah hubungan sebab akibat. Perbaiki akhlak kecantikan wajah akan mengikuti (informan nomor 5). Selanjutnya, informan nomor 8 memberikan saran agar merasa banggalah terhadap diri sendiri dan tunjukkan kelebihan-kelebihan yang dimiliki, karena 
sejatinya tiap individu memiliki kelebihan yang mampu dijadikan 'penutup' kekurangan individu. Selain itu selalu bersyukur, berbuat baik, berakhlak mulia, dan membantu kemanusiaan untuk menambah kecantikan fisik yang dimiliki (informan no 8).

Dari sudut pandang agama Islam, informan nomor 12 menyatakan bahwa cantik itu sunnah, tetapi jangan sampai dilakukan secara berlebihan sehingga menimbulkan riya' dan tabarruj. Tetaplah jadi diri sendiri tanpa mengubah bentuk dan kodrat yang diberikan Allah. Tabarruj berarti memperlihatkan dihadapan laki-laki yang bukan mahramnya perhiasannya dan juga anggota-anggota tubuhnya. Disebutkan oleh Allah Subhanahu wa Ta'ala di dalam Al-Qur'an, yaitu ketika menceritakan tentang para wanita-wanita Arab jahiliyah, Allah Subhanahu wa Ta'ala berfirman:

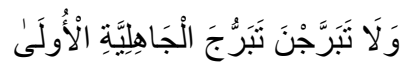

"...dan janganlah kamu berbias dan bertingkah laku seperti orang-orang Jabiliyah yang dabulu ...” (QS. Al-Ahzab : 33)

Ayat ini meminta perempuan untuk tidak menampakkan keindahan dirinya seperti kebiasaan perempuan pada masa sebelum datangnya Islam yang bertujuan untuk menggoda laki-laki. Perempuan sering menjadi sasaran empuk bagi perkembangan mode. Alat-alat kosmetik, parfum, hingga model pakaian yang lagi tren, dengan cepat dikonsumsi mereka. Setelah berpenampilan sesuai dengan trend terbaru, mereka biasanya mengunjungi tempattempat keramaian sehingga berpotensi menimbulkan fitnah. Larangan tabarruj tidak hanya ditujuan kepada istri-istri Rasulullah yang merupakan pendamping manusia pilihan, tetapi kepada seluruh perempuan karena tabarruj dapat menimbulkan fitnah bagi laki-laki. Laki-laki secara alami memiliki ketertarikan kepadaperempuan sehingga dapat tergoda melihat perempuan keluar dengan keindahannya. Selain itu, Surat An-Nur ayat 60 juga menunjukkan bahwa larangan untuk tabarruj tidak hanya dikhususkan bagi ummahatul mukminin, akan tetapijuga berlaku bagi seluruh mukminah. Bila perempuan yang sudah tua dan sudah mengalami menopause saja dilarang tabarruj sebagaimana dalam ayat tersebut tentunya larangan kepada perempuan yang masih muda lebih utama lagi.

Selain pelarangan untuk bertabarruj, terdapat pula larangan untuk mengubah ciptaan Allah sebagaimana pada hadits berikut.

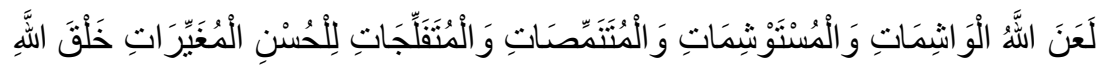


Artinya: Allah melaknat orang yang mentato dan yang minta ditato dan mencukur habis alis mata serta merenggangkan gigi (dengan kawat dll) untuk kecantikan dengan merubah ciptaan Allab (Hadits Bukbari No. 5487)

Larangan sebagaimana disebut pada hadits diatas berlaku bagi perempuan maupun lakilaki. Laknat Allah SWT menunjukkan keharamannya, dan bahkan ada ulama yang mengkategorikannya termasuk kepada dosa besar. Pada umumnya laknat hanya ditujukan kepada perbuatan yang haram dan tingkat keharamannyaberat. Diantara landasan atas dosa besar adalah berupa ancaman laknat, murka, neraka, ancaman atau hukuman didunia. Selain larangan bertato, terdapat pula larangan mencukur alis. Mencukur, mengerik atau menghilangkan baik sebagian atau seluruh alis tetap saja dilarang. Pada umumnya hal ini sering dilakukan oleh perempuan ketika akan menikah dengan tujuan untuk terlihat lebih cantik. Namun trend saat ini mencukur alis tidak hanya dilakukan pada saat akan menikah, namun untuk penampilan sehari-hari. Bahkan dalam dunia kecantikan saat ini banyak terdapat jasa sulam alis dan tato alis yang ditawarkan oleh klinik-klinik kecantikan.

Berdasarkan pembahasan tersebut, maka ketika seorang perempuan muslimah ingin mempercantik dirinya hendaklah mematuhi ajaran agama tentang berhias. Mengejar standar cantik yang hanya semata-mata berdasarkan ukuran fisik tentu saja akan kurang sempurna jika tidak dibarengi dengan kecantikan hati yang tercermin dari akhlak yang baik dan terpuji. Apa gunanya fisik yang cantik namun sering menyakiti orang lain akibat dari perkataan dan perbuatannya. Mengejar kecantikan luar dalam akan membuat perempuan menjadi lebih bernilai positif dan membawa manfaat atas keberadaannya di dunia ini.

\section{SIMPULAN}

Cantik, sebagai suatu kondisi yang banyak diidam-idamkan perempuan, ternyata memiliki standar yang relatif di masyarakat. Ada yang mendefinisikan cantik hanya dari sisi fisik, ada yang dari sisi perilaku, dan ada pula yang merupakan gabungan dari keduanya. Cantik dari sisi fisik berdasarkan pendapat informan dalam penelitian ini didominasi oleh kecantikan dengan ciri-ciri yang ada pada artis dan figure publik lainnnya. Keinginan mengejar standar cantik kadangkala dapat mengakibatkan hal yang negatif seperti diet yang berlebihan sehingga membahayakan kesehatan, rasa rendah diri, dan juga body shaming. Untuk mengatasi dampak negatif tersebut, ada dua strategi coping yang dapat dilakukan yaitu strategi coping yang 
memfokuskan pada memecahkan masalah dan strategi coping yang memfokuskan pada modifikasi emosi. Dengan dua strategi ini diharapkan para perempuan dapat melakukan coping positif dalam mengatasi masalah standarisasi cantik perempuan, sehingga tetap memiliki rasa percaya diri yang tinggi dan terus menjalani hidup dengan semangat.

\section{DAFTAR PUSTAKA}

Afif, Afthonul. (2015). Teori Identitas Sosial. Yogyakarta, Yogyakarta: UII Press.

Aprilita, D. (2016). Representasi Kecantikan Perempuan dalam Media Sosial Instagram (Analisis Semiotika Roland Barthes pada Akun@mostbeautyindo,@Bidadarisurga, dan@papuan_girl).Paradigma,4 (3).

Arsitowati, W. H. (2018). Kecantikan Perempuan Korea Sebagai Konsep Kecantikan Ideal dalam Iklan New Pond's White Beauty: What Our Brand Ambassador Are Saying. HUMANIKA, 24 (2).

Bohang, Fatimah K. (2018). Pengguna Aktif Instagram Tembus 1 Miliar. Retrieve from https://tekno.kompas.com/, (2018, Juni 21). Juni 2018.

Chervenic, B. (2015). Is Beauty a Promise to Happiness?. New Errands: The Undergraduate Journal of American Studies, 2 (2).

Chin Evans, P., \& McConnell, A. R. (2003). Do Racial Minorities Respond in the Same Way to Mainstream Beauty Standards? Social Comparison Processes in Asian, Black, and White Women. Self and Identity, 2 (2), 153-167.

Hermansyah. (2011). Kontes Kecantikan dan Eksploitasi Perempuan dalam Media, Marwah: Jurnal Perempuan, Agama, dan Jender, 10 (2), 26-38.

Julian, R. (2016). Mitos Kecantikan Dalam Cerpen-Cerpen Dwi Ratih Ramadhany, Jurnal POETIKA, 4 (1), 52-60.

Kharizta, S. P. (2018). Hubungan antara Self Esteem dengan Body Image pada Remaja Putri Followers Body Goals di Instagram. Doctoral Dissertation, UIN Sunan Gunung Djati Bandung.

Murwani, E. (2010). Konstruksi 'Bentuk Tubuh Perempuan' dalam Iklan Televisi. ULTIMA Comm, 2 (1), 10-19.

Nasiha, N. F. (2017). Pengaruh Penggunaan Media Sosial Instagram Terhadap Citra Tubuh Mahasiswa Fakultas Ushuluddin Adab dan Dakwah IAIN Ponorogo Tahun 2016, Dialogia: Jurnal Studi Islam dan Sosial, 15 (2), 333-351.

Permata, I. M., \& Nanda, B. J. (2017). Pasar Kecantikan dan Penindasan Perempuan di Cina, Andalas Journal of International Studies (AJIS), 6 (2), 93-108.

Pradewo, Bintang. (2018). 4 Penyebab Body Shaming. Hukum \& Kriminal, Retrieve from www.jawapos.com, 25 November 2018. 
Prianti, D. D. (2013). Indonesian female beauty concept: Does it take into account the traditional values?, Proceedings of The Asian Conference on Media and Mass Communication. pp. 346-357. Osaka: IAFOR.

Putri, B. A. S., Kuntjara, A. P., \& Sutanto, R. P. (2018) "Perancangan Kampanye “Sizter's Project” sebagai Upaya Pencegahan Body Shaming. Jurnal DKV Adiwarna, 1(12), 9.

Sarwer, D. B. Grossbart, T. A., \& Didie, E. R. (2003). Beauty and Society, In Seminars in Cutaneous Medicine and Surgery, Vol. 22, No. 2, 79-92.

Suhardono, E. (2016). Teori Peran: Konsep, Derivasi dan Implikasinya. Jakarta: Gramedia Pustaka Utama.

Wijayanti, Mita. (2018). Hedonisme Sebagai Identitas Pengguna Media Sosial Instagram. Skripsi, Universitas Lampung.

Wolf, N. (2002). The Beauty Myth: How Images of Beanty are Used Against Women. New York: Harperperennial Library. 